\title{
ОРГАНІЗАЦІЯ ОБЛІКУ ДЕБІТОРСЬКОЇ ЗАБОРГОВАНОСТІ ТА ШЛЯХИ ІІІ ВДОСКОНАЛЕННЯ
}

\section{ORGANIZATION OF ACCOUNTING RECEIVABLES AND WAYS OF ITS IMPROVEMENT}

\author{
Кравченко Олена Володимирівна \\ кандидат економічних наук, доцент, \\ Сумський державний університет \\ ORCID: https://orcid.org/0000-0001-5927-8814 \\ Кобець Тетяна Олександрівна \\ студентка, \\ Сумський державний університет \\ ORCID: https://orcid.org/0000-0001-5891-791X
Kravchenko Olena, Kobets Tatiana
Sumy State University

\begin{abstract}
У статті досліджено теоретичні та методологічні основи організації обліку дебіторської заборгованості. Розглянуто економічну сутність дебіторської заборгованості та її виникнення в сучасних умовах господарювання. Відображено класифікаційні ознаки щодо дебіторської заборгованості. Особливу увагу приділено питанням формування обліковій політиці в частині дебіторської заборгованості. Наведено її основні елементи, що потребують розкриття в Наказі про облікову політику підприємства. Згруповано фрактори, які впливають на виникнення та збільшення дебіторської заборгованості на підприємстві. Визначено шляхи вдосконалення організації обліку дебіторської заборгованості через додаткові умови комерційного кредитування, введення аналітичних та субрахунків до робочого плану рахунків підприємства.

Ключові слова: дебіторська заборгованість, дебітор, облік, класифікація, облікова політика, фрактори, визнання та оцінка.

В статье исследованы теоретические и методологические основы организации учета дебиторской задолженности. Рассмотрена экономическая сущность дебиторской задолженности и ее возникновение в современных условиях хозяйствования. Отражены классификационные признаки дебиторской задолженности. Особое внимание уделено вопросам формирования учетной политики относительно дебиторской задолженности. Приведены ее основные элементы, требующие раскрытия в Приказе об учетной политике предприятия. Сгруппированы фракторы, влияющие на возникновение и увеличение дебиторской задолженности на предприятии. Определены направления совершенствования организации учета дебиторской задолженности через дополнительные условия коммерческого кредитования, введение аналитических и субсчетов в рабочий план счетов предприятия.
\end{abstract}

Ключевые слова: дебиторская задолженность, дебитор, учет, классисикация, учетная политика, фракторы, признание и оценка.

The article investigates the theoretical and methodological foundations of the organization of receivables accounting. In modern conditions, it is necessary to accurately reflect the calculations with debtors, which will rationally use the financial resources of the enterprise and the national economy as a whole. When considering receivables, it is necessary to control the causes of bad and overdue debts. In addition, it is necessary to control the correctness and timeliness of the inventory of receivables. Controlling the receivables of the enterprise, it is necessary to check the correctness of its assignment to prevent unjustified reduction of taxable profits of enterprises. The economic essence of receivables and its occurrence in modern business conditions is considered. The classification features of receivables are reflected. Particular attention is paid to the formation of accounting policies in terms of receivables. Its main elements that need to be disclosed in the Order on the accounting policy of the enterprise are given. Factors influencing the emergence and increase of receivables in the enterprise are grouped. Ways to improve the organization of accounting for receivables through additional conditions of commercial lending, the introduction of analytical and sub-accounts in the work plan of the company's accounts. The considered ways of improvement of the orga- 
nization of accounting promote increase of efficiency of a managerial aspect of receivables. Effective management of receivables has a significant impact on liquidity, on the overall financial stability of the enterprise. Enterprises, taking into account the specifics of the activity, the set goals, within the current legislation must independently form a system of accounting for receivables. This will ensure the formation of reliable, efficient and high-quality information for receivables management. Such information within the debtor's management regarding its size and term of receipt is received by interested external and internal users for making appropriate decisions. In addition to the organization of debtors, the department provides control over the financial condition and performance of the enterprise. The article considers the main directions in the organization of receivables management and summarizes the results of incomplete receivables management. This article also substantiated the main types of receivables and the features of their impact. This article also considered the impossibility of choosing reliable and solvent potential buyers and consumers. Ways to improve receivables are defined in this article. The methodological and informational basis of this work is Internet resources, regulations, periodicals and scientific papers.

Keywords: receivables, debtor, accounting, classification, accounting policies, factors, recognition and measurement.

Постановка проблеми. Підприємство може мати дебіторську заборгованість під час операцій з дебіторами (боржниками). Статистичні дані щодо динаміки дебіторської заборгованості на підприємствах свідчать, що ії обсяги зростають щороку. Наявність такої заборгованості суттєво впливає на ліквідність активів, фрінансовий стан та платоспроможність підприємства. Стан бухгалтерського обліку може погіршитися через незадовільну організацію, але належний облік дебіторської заборгованості дозволяє більш раціонально управляти боргом, строком погашення та зменшувати ймовірність виникнення безнадійної заборгованості. Саме тому кожне підприємство зацікавлене в оптимізації дебіторської заборгованості, в тому числі й через формування достовірної та своєчасної облікової інфрормації про стан розрахунків з різними дебіторами.

Аналіз останніх досліджень і публікацій. Дослідженню питань регулювання організації та вдосконалення бухгалтерського обліку дебіторської заборгованості присвячені праці багатьох зарубіжних та вітчизняних економістів: П.Є. Житнього [1], О.Ю. Закревської [4], О.О. Сидоренко [6], Л.М. Васильєва [7] та інші.

Виділення невирішених раніше частин загальної проблеми. Під час опрацювання наукової літератури за темою дослідження ми прийшли до висновку, що невирішеними залишаються певні теоретичні та практичні питання щодо створення єдиного підходу до вивчення сутності та причин походження, організації обліку, фрорм та особливостей управління дебіторською заборгованістю.

Формулювання цілей статті. Метою статті $\epsilon$ розкриття теоретично-методичних особливостей організації обліку дебіторської заборгованості та визначення способів удосконалення даного процесу.

Виклад основного матеріалу. Реалізація функцій організаційного управління дебітор- ської заборгованості вимагає вирішення різних проблем, наприклад, дослідження економічної сутності дебіторської заборгованості та ії виникнення в сучасних умовах господарювання. Слід зазначити, що вітчизняні та зарубіжні вчені по-різному трактують поняття «дебіторська заборгованість»: 3 бухгалтерського, економічного, юридичного аспекту (рис. 1).

Отже, узагальнюючи, можна стверджувати, що дебіторська заборгованість - це сума боргів, належних підприємству, виникнення яких відбулося внаслідок ведення господарської діяльності, а погашення відбудеться в майбутньому. Питання щодо класифікації дебіторської заборгованості досліджували багато вчених. Серед них можна відмітити А.Ю. Волостникову, думку якої ми поділяємо. Вона наводить класифрікаційні ознаки, що більш детально розкривають діяльність підприємства та дозволяють отримати всебічну інформацію про заборгованість (табл. 1).

Процес організації обліку дебіторської заборгованості повинен розпочинатися зі створення якісної облікової політики. На даний процес впливають різні фрактори, найбільш вагомими серед них є: галузева приналежність виду діяльності, яка визначає основні елементи, що потребують розкриття. В Наказі про облікову політику слід вказати інформацію щодо:

- визначення об'єктів обліку;

- визначення класифрікації;

- визнання та оцінка;

- документальне оформлення операцій;

- вибір методу формування РСБ;

- порядок списання безнадійної заборгованості;

- організація контролю;

- порядок проведення інвентаризації;

- відображення інформації у фрінансовій звітності.

Наприклад, документальне офрормлення операцій дебіторської заборгованості дозво- 


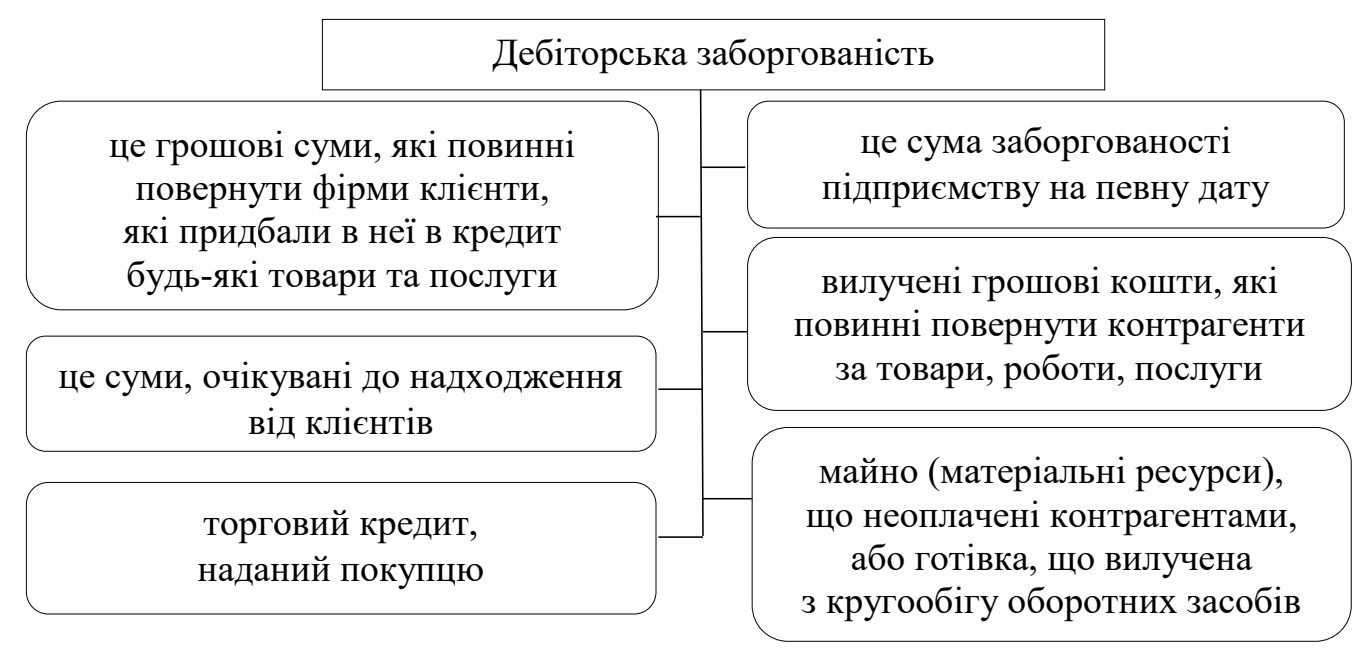

Рис. 1. Підходи визначення поняття «дебіторська заборгованість»

Джерело: складено автором за даними джерел [1-6]

ляє засвідчити фракт досягнення домовленості між дебітором і відповідним підприємством, щоб уникнути неправильного розуміння сторонами взятих на себе обов'язків, умов їх виконання та відповідальності. Визначення класифрікаційних ознак, видів дебіторської заборгованості дозволять підвищити аналітичність обліку задля управлінських потреб

Класифрікація дебіторської заборгованості

Таблиця 1

\begin{tabular}{|c|c|c|}
\hline № & Класифікаційна ознака & Види дебіторської заборгованості \\
\hline 1 & За тривалістю & $\begin{array}{l}\text { - довгострокова; } \\
\text { - короткострокова. }\end{array}$ \\
\hline 2 & За терміном виконання зобов'язань & $\begin{array}{l}\text { - поточна; } \\
\text { - прострочена. }\end{array}$ \\
\hline 3 & За характером діяльності організації & $\begin{array}{l}\text { - за основною діяльністю; } \\
\text { - за фрінансовою діяльністю; } \\
\text { - за інвестиційною діяльністю. }\end{array}$ \\
\hline 4 & За видами дебіторів & $\begin{array}{l}\text { - покупців і замовників; } \\
\text { - дочірніх підприємств; } \\
\text { - працівників підприємств; } \\
\text { - бюджету і позабюджетних фондів. }\end{array}$ \\
\hline 5 & За доцільністю утворення & $\begin{array}{l}\text { - виправдана; } \\
\text { - невиправдана. }\end{array}$ \\
\hline 6 & За регулярністю проведення угод & $\begin{array}{l}\text { - від регулярних угод; } \\
\text { - від нерегулярних угод. }\end{array}$ \\
\hline 7 & За якісним складом & $\begin{array}{l}\text { - нереальна для стягнення; } \\
\text { - сумнівна; } \\
\text { - надійна. }\end{array}$ \\
\hline 8 & За можливістю поступки прав вимоги & $\begin{array}{l}\text { - можна передати за договором; } \\
\text { - заборгованість, яку заборонено передавати. }\end{array}$ \\
\hline 9 & За забезпеченістю гарантіями & $\begin{array}{l}\text { - забезпечена; } \\
\text { - незабезпечена. }\end{array}$ \\
\hline 10 & За ступенем ризику & $\begin{array}{l}\text { - } 3 \text { високим ризиком; } \\
\text { - } 3 \text { середнім ризиком; } \\
\text { - } 3 \text { низьким ризиком. }\end{array}$ \\
\hline 11 & За можливістю планування & $\begin{array}{l}\text { - запланована; } \\
\text { - незапланована. }\end{array}$ \\
\hline 12 & За можливістю контролю & $\begin{array}{l}\text { - контрольована; } \\
\text { - неконтрольована. }\end{array}$ \\
\hline
\end{tabular}

Джерело: [5, с. 45] 
конкретного підприємства. Порядок визнання дебіторської заборгованості як активу та її оцінка повинні відповідати вимогам концепції управління вартістю підприємства. Особливу увагу, враховуючи принцип обачності, слід приділити розкриттю інфрормації щодо резерву сумнівних боргів (РСБ).

Підприємство не може вносити зміни до облікової політики, крім певних випадків. Зміни можуть відбуватися лише у випадках, передбачених національними стандартами: бути обов'язковими і такими, що здійснюються на розсуд самого підприємства.

При підготовці обліково-аналітичної інсрормації щодо дебіторської заборгованості потрібно визначити причини ії̈ виникнення та збільшення (рис. 2). Якщо зовнішні причини підприємство не може контролювати та обмежити їх вплив на власну діяльність, то внутрішні - залежать від стану організаційних процесів на підприємстві, можна послабити їх вплив через належну систему управління.

Саме тому на підприємствах необхідно приділяти значну увагу питанням удосконалення обліку дебіторської заборгованості через систему ефективного управління, яка безпосередньо впливає на рівень прибутковості підприємства. 3 цією метою доцільно застосовувати такі заходи:

- визначити основні критерії торгівельного кредиту;

- контролювати рівень заборгованості;
- класифрікувати дебіторську заборгованість за видами;

- дослідити основні групи споживачів, яких небажано втрачати;

- проводити періодичний аналіз дебіторів;

- виділити групи контрагентів (неплатників), які не відповідають вимогам та яким необхідно подати термінові вимоги щодо погашення;

- визначити типи активів, які можуть спричинити заборгованість;

- використовувати сучасні методи управління заборгованістю.

Вдосконалення системи відбору потенційних замовників та покупців дозволить підприємству попередньо перевірити клієнта на можливість своєчасного погашення ними зобов'язання. Фактори, які вплинуть на рішення підприємства про співпрацю 3 дебіторами, можуть включати:

- низьку платіжну дисципліну покупця;

- нестача коштів клієнтів або зниження рівня платоспроможності;

- порушення дисципліни розрахунків та платежів;

- створення на підприємстві кредитний рейтинг клієнта, який показує клієнта чи він з низьким рейтингом, чи ні. Звичайно, такий спосіб відбору не може гарантувати, що навіть найкращі покупці вчасно закриють свій борг підприємству.

Пропонуємо вказати в договорі додаткові умови комерційного кредитування, а також

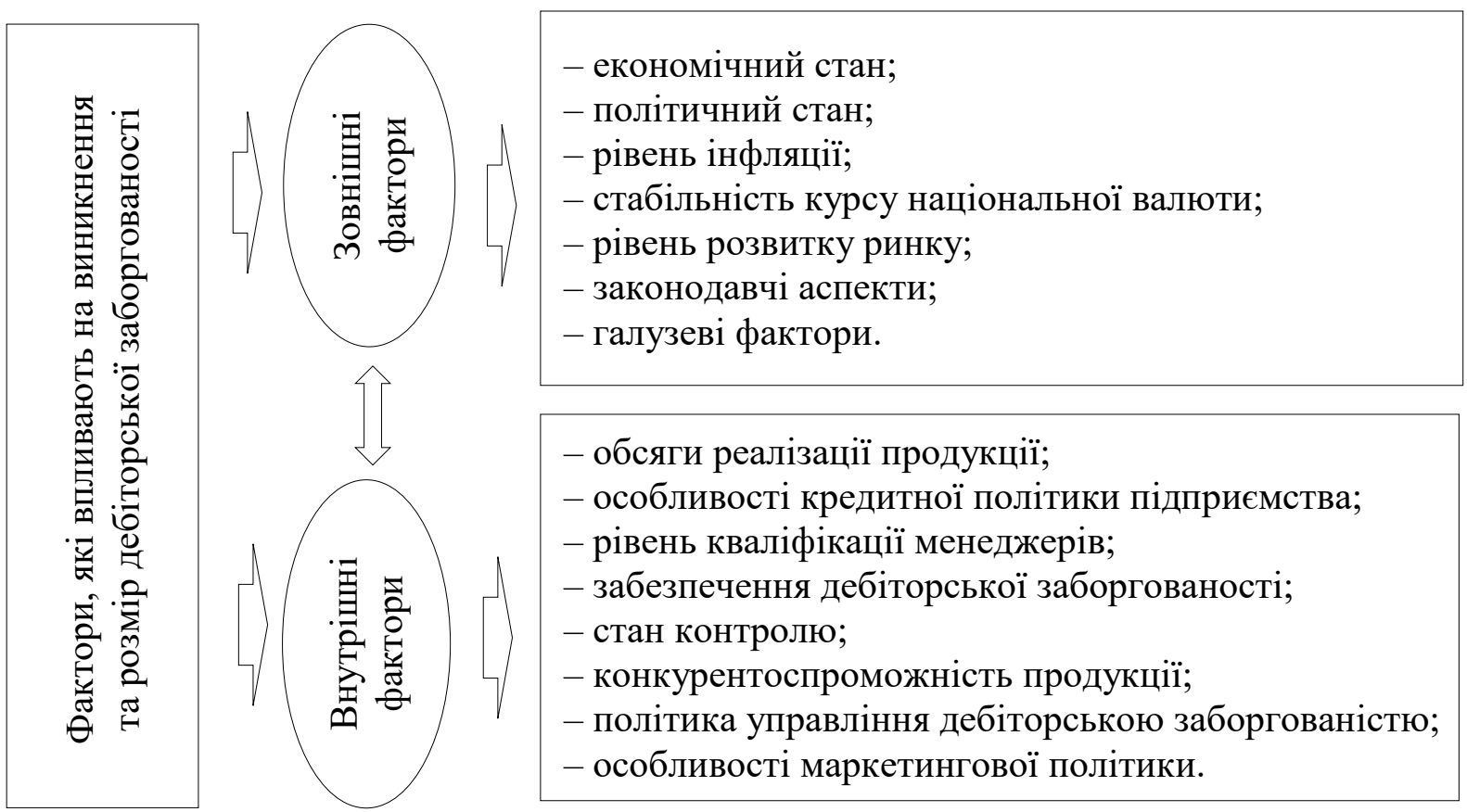

Рис. 2. Фактори, які впливають на виникнення та збільшення дебіторської заборгованості 
систему штрафнних санкцій за прострочення виконання зобов'язань покупцями. Альтернативною фрормою оплати в цьому випадку може бути:

- аванс у негрошовій фрормі (високоліквідні цінні папери, товари, активи, які можна швидко перетворити на гроші);

- біржові операції (підприємство може вирішити, що за певних обставин підприємство обміняє ТМЦ на свою продукцію. Угода про обмін укладається в єдиному договорі, в якому оцінка товарів і послуг виконується на основі договірної ціни [3, с. 67].

Важливим аспектом в організації бухгалтерського обліку $є$ розробка фрункціонального робочого плану рахунків. Кожне підприємство формує його з урахуванням власної специфріки. При розрахунках з дебіторами застосовується 36 рахунок «Розрахунки з покупцями та замовниками», або 37 рахунок «Розрахунки з різними дебіторами». На нашу думку, доцільним для кожного підприємства буде відкриття певних субрахунків до цих рахунків. Наприклад, додати субрахунок 365 «Розрахунок з відстроченим платежем» до рахунку 36, де накопичувати інформацію про операції щодо дебіторської заборгованості у випадку відстрочення зобов'язання відповідно укладеного договору. Це дозволить чітко визначити розмір боргу, за якого потрібно нарахувати РСБ. Оскільки 36 рахунок має відповідні субрахунки 361 «Розрахунки 3 вітчизняними покупцями» та субрахунок «Розрахунки з іноземними покупцями», тому рекомендуємо до цього рахунку запропонувати субрахунок 366 «Розрахунки 3 вітчизняними замовниками» та 367 «Розрахунки 3 іноземними замовниками» задля підвищення аналітич- ності розрахунків, бо відокремлення покупців від замовників в такому форматі дозволить розподілити готову продукцію замовникам та реалізовані товари покупцям.

До субрахунку 371 «Розрахунки за виданими авансами» рекомендуємо додати такі субрахунки: 3711 «Розрахунки за виданими авансами постачальникам», 3712 Розрахунки за виданими авансами постачальникам», до субрахунку 372 «Розрахунки 3 підзвітними особами»: 3721 «Розрахунки за службовим відрядженням», 3722 «Розрахунок за реалізацію сільськогосподарської продукції» та 3723 «Утримання із зарплати неповернутих сум» для відокремлення різних видів розрахунків, підвищення аналітичної складової інорормації.

Висновки. Отже, дебіторська заборгованість $€$ важливим показником фрінансового стану підприємства. Ефрективне управління дебіторською заборгованістю має значний вплив на ліквідність, на загальну фрінансову стійкість підприємства. Підприємства, враховуючи специфріку діяльності, поставлені цілі, в межах чинного законодавства повинні самостійно фрормувати систему обліку дебіторської заборгованості. Це дозволить забезпечити орормування достовірної, оперативної та якісної інфрормацію для управління дебіторською заборгованістю на підприємстві. Розглянуті нами шляхи вдосконалення організації обліку сприятимуть підвищенню ефективності управлінського аспекту дебіторської заборгованості. Перспективи подальших досліджень будуть спрямовані на побудову ефрективного механізму внутрішнього контролю дебіторської заборгованості на підприємствах задля попередження виникнення нової.

\section{СПИСОК ВИКОРИСТАНИХ ДЖЕРЕЛ:}

1. Житний П.Є., Афанас'єва І.І. Фактори впливу на фрормування облікової політики торгово-виробничих підприємств. Вісник ЖДТУ. № 1(51). URL: http://ven.ztu.edu.ua/article/viewFile/68936/64942

2. Діяльність суб'єктів господарювання за 2016 рік : стат. зб. Державна служба статистики України, 2019. URL: http://www.ukrstat.gov.ua

3. Кужельний М.В. Теорія бухгалтерського обліку. Київ : КНЕУ, 2011. 334 с.

4. Загородній А.Г. Бухгалтерський облік: основи теорії і практики. Львів : Видавництво Львівської політехніки, 2018. 280 с.

5. Волостникова А.Ю. Проблемы учетно-аналитического обеспечения дебиторской и кредиторской задолжености предприятия : авторефр. дис. канд. эконом. наук : спец. 08.00.12 «Бухгалтерский учет, статистика». Москва, 2009. 22 с.

6. Сидоренко О.О. Визнання, класифікація та окремі аспекти обліку дебіторської заборгованості у суб'єктів господарювання. Інфраструктура ринку. 2019. Вип. 32. С. 449-456.

7. Васільєва Л.М., Трайно О.В. Організація обліку дебіторської заборгованості та шляхи їі удосконалення. Молодий вчений. 2017. № 10(50). С. 820-823.

8. Закревська О.Ю. Організація бухгалтерського обліку поточної дебіторської заборгованості підприємства торгівлі. Причорноморські економічні студії. 2017. Вип. 20. С. 103-106. 
9. Організація бухгалтерського обліку : навчальний посібник / За ред. В.С. Леня. Київ : Центр навчальної літератури, 2006. 696 с.

10. Кундря-Висоцька О.П., Москаленко О.В., Сулима М.О. Організація бухгалтерського обліку : навч. посібник. Київ : УБС НБУ, 2015. 298 С.

\section{REFERENCES:}

1. Zhytnyi P.E., Afanaseva I.I. Factory vplyvu na formuvannya oblikovoi polityky torgovo-vyrobnuchuh pidpryemstv [Factors influencing the formation of the accounting policy of trade and production enterprises]. URL: http://ven.ztu.edu.ua/article/viewFile/68936/64942

2. Deyalnist subiectiv gospodaruyvannya za 2016 rik: stat. zb. [Activities of economic entities for 2016 year: statistical yearbook]. 2017. URL: http://www.ukrstat.gov.ua

3. Kuzhelnyi M.V. (2011) Teoriya buhalterskogo obliku [Theory of accounting]. Kyiv, 334 p.

4. Zagorodniy A.G. (2018) Buhalterskyi oblik: osnovy teorii i practyky [Accounting: Fundamentals of Theory and Practice]. Lviv, $280 \mathrm{p}$.

5. Volostnykova A.lu. (2009) Problemy uchetno-analytycheskoho obespechenyia debytorskoi y kredytorskoi zadolzhenosty predpryiatyia [The problems of accounting and analytical support of receivables and payables of the enterprise] (PhD Thesis), Moscow: NGY.

6. Sidorenko A.A. (2019) Vyznannia, klasyfikatsiia ta okremi aspekty obliku debitorskoi zaborhovanosti u subiektiv gospodariuvannia [Recognition, classification and individual aspects of the accounting of accounts receivable by business subjects]. Market Infrastructure, vol. 32, pp. 449-456.

7. Vasilieva L.M., Traino A.V. (2017) Orhanizatsiia obliku debitorskoi zaborhovanosti ta shliahy ii udoskonalennia [The organization of accounts receivable and the ways of its improvement]. Young Scientist, no. 10(50), pp. 820-823.

8. Zakrevska O.lu. (2017) Orhanizatsiia bukhhalterskoho obliku potochnoi debitorskoi zaborhovanosti pidpryiemstva torhivli [The organization of accounting of current receivables of trade enterprises]. Black Sea Economic Studies, vol. 20, pp. 103-106.

9. Len V.S. (2006) Orhanizatsiia bukhhalterskoho obliku [Organization of accounting]. Kyiv: Tsentr navchalnoi literatury. (in Ukrainian)

10. Kundria-Vysotska O.P., Moskalenko O.V., Sulyma M.O. (2015) Orhanizatsiia bukhhalterskoho obliku [Organization of accounting]. Kyiv: UBS NBU. (in Ukrainian) 